ОБРАЗОВАНИЕ И ОБУЧЕНИЕ: МЕТОДОЛОГИЯ, ТЕОРИЯ, ТЕХНОЛОГИЯ БІЛІМ БЕРУ ЖӘНЕ ОҚЫТУ: ӘДІСТЕМЕ, ТЕОРИЯ, ТЕХНОЛОГИЯ EDUCATION AND TRAINING: METHODOLOGY, THEORY, TECHNOLOGY

\author{
FTAXP 82.13.31 \\ ӘОЖ 354 \\ https://doi.org/10.46914/1562-2959-2021-1-4-216-223
}

\author{
Ш.К. СУЛЕЙМЕНОВА, \\ докторант. \\ *e-mail: sh.suleimenova@apa.kz \\ ${ }^{1}$ Қазақстан Республикасы Президенті \\ жанындағы Мемлекеттік басқару академиясы, \\ Қазақстан, Нұр-Сұлтан қ.
}

\author{
ЖОҒАРЫ БІЛІМ САПАСЫН БАСКАРУ ЖҮЙЕЛЕРІ \\ (АҚШ, ҰЛЫБРИТАНИЯ, НОРВЕГИЯ ЖӘНЕ ФИНЛЯНДИЯ МЫСАЛЫНДА)
}

\begin{abstract}
Андатпа
Қазақстан қазіргі кезеңде өсіп келе жатқан жаһанданудан туындаған жаңа әлеуметтік-саяси, экономикалық және халықаралық жағдайларда тұр. Бұл, бір жағынан, Қазақстанның білім беру жүйесінің дамуына әлемдік білім беру үрдістерінің елеулі әсерін негіздейді, екінші жағынан, ұлттық экономиканың нарықтық сипаты білімнің, білім беру қызметтерінің, атап айтқанда, білімді капиталдандыру арқылы ел экономикасы мен оның дамуына әсерінің сөзсіздігін айқындайды. Қазіргі уақытта қазақстандық жоғары оқу орындары әлемдік және отандық экономикада қалыптасқан үрдістерге сәйкес дамуда, олардың арасында жаһандану ерекше орын алады. Қазіргі заманғы қазақстандық жоғары білім беру үшін әлемдік білім беру кеңістігіне интеграциялануға ұмтылу тән. Бұл мақаланың мақсаты - кейбір Еуропа елдері мен АҚШ мысалында жоғары білім сапасын басқарудағы халықаралық тәжірибені зерттеу. Әлемдік білім беру кеңістігіндегі жоғары білім сапасын басқарудың заманауи екі моделі сипатталып, Қазақстандағы жоғары білім сапасын бағалау моделі айқындалды. Мемлекеттік бақылау және жоғары білім сапасын бағалау саласындағы қазақстандық заңнамаға талдау жүргізілді. Қарастырылып отырған шет мемлекеттердің үлгісі бойынша, қазақстандық жоғары білім беру жүйесі үшін жоғары білім сапасын бағалаудың ең жақсы тәсілдері анықталды. Мақаланы жазу үшін құқықтық актілер мен құжаттарды талдау, кейс-стади, дедукция және жалпылау сияқты зерттеу әдістері пайдаланылды.
\end{abstract}

Тірек сөздер: мемлекеттік басқару, жоғары білім, сапаны басқару, бағалау, аккредиттеу, әлемдік білім беру кеңістігі, талдау.

\title{
Кіріспе
}

Көптеген елдерде білім беру сапасын арттыру, азаматтардың зияткерлік әлеуетін сақтау және экономиканың тұрақты өсуін сақтау негізгі стратегиялық міндет болып табылады. Қазақстан Республикасының 2025 ж. дейінгі жалпыұлттық дамуының басым бағыттарының бірі - ел дамуының жаңа бағытын іске асыру үшін адами капиталды дамыту болып айқындалған. Бұл үшін стратегиялық бағыт мемлекеттік реттеуден бастап, академиялық еркіндік пен адалдық, жоғары оқу орындарының білім сапасы үшін жауапкершілігі қағидаттарына негізделген, өзін-өзі реттейтін ортаны дамытуға қарай басталған трансформацияны жалғастыруға шоғырландырылатын болады [1].

\section{Негізгі ережелері}

2018 ж. бастап мемлекет жоғары оқу орындары үшін академиялық автономияны және басқарушылық дербестікті ұлғайтуды қамтамасыз етті. Қазақстандық жоғары оқу орындары үшін 
Қазақстан Республикасының «Білім туралы» Заңына олардың құзыреттерін айқындайтын жаңа бап енгізілді, бұл нормативтік-құқықтық актілер санының, орталықтандырылған нормалар мен шектеулердің азаюына, мемлекеттік тікелей басқарудан орталықсыздандырылған басқаруға көшуге әсер етті.

Мұндай жағдайларда мемлекет үшін жоғары білім беру сапасын арттыру және сақтау маңызды мәселе, бұл жоғары оқу орындарының мемлекет пен қоғам алдындағы ашықтығын, айқындығы мен есептілігін талап етеді. Бұл келесі факторларға да байланысты:

a) кадрларды даярлау және жоғары оқу орындарын дамыту үшін мемлекеттік бюджетті ұлғайту, бұл басқа әлеуметтік салалармен салыстырғанда жоғары білімнің артықшылықтарын көрсетеді;

ә) жаһандану және әлемдік білім беру кеңістігіне ену жағдайында кадрлар даярлау сапасына назардың күшеюі;

б) сандық ресурстардың, әлеуметтік желілердің дамуына байланысты қазіргі қоғамның көптеген салаларында «ашықтықтың» артуы, бұл университеттен тыс оның қызметі туралы ақпарат алуға мүмкіндік береді.

Осылайша, бұл үрдістер уәкілетті мемлекеттік орган тарапынан мемлекеттік басқару үшін де, сондай-ақ жалпы сапа мәдениетін қалыптастыру мақсатында жоғары оқу орындары үшін де жоғары білім сапасын мониторингтеу және бағалау нысандары мен құралдарының өзгеруіне әсер етеді.

\section{Материалдар мен әдістер}

Осы мақаладағы негізгі зерттеу әдістері жүйелік талдау, алынған ақпаратты синтездеу және тұжырымдау әдісі болды. Атап айтқанда, заңнамалық база қарастырылды, оның ішінде жоғары білім берудің сапасын бақылау мен бағалауға қатысты құқықтық актілер және жалпыға қол жетімді ресми құжаттардан алынған эмпирикалық мәліметтер талданды. Сондай-ақ, жоғары білім берудің сапасын қамтамасыз ету бойынша шетелдік тәжірибені көрсететін нақты кейстер қарастырылды, дедукция, жалпылау сияқты жалпы ғылыми зерттеу әдістері қолданылды.

\section{Нәтижелер}

Білім беру кеңістігінде жоғары білім беру сапасының кепілдіктері оның сапасының деңгейін көрсететін көрсеткіштер жүйесі (білім беру ортасы, білім беру бағдарламаларының мазмұны, түлектерді жұмысқа орналастыру, профессорлық-оқытушылық құрам) ретінде түсініледі. Кепілдіктерді қамтамасыз ету дәрежесін анықтау үшін жоғары білім сапасын бағалау қажет.

Қазіргі кезеңде әлемдік тәжірибеде жоғары білім сапасының деңгейін анықтау және өлшеу үшін сапаны бағалаудың әртүрлі жүйелері қалыптасып, қолданылып жүр, олар көптеген зерттеулерде шартты түрде екі түрге бөлінеді:

Бірінші түрі - білім беру министрліктері немесе мамандандырылған мемлекеттік органдар тарапынан орталықтандырылған басқару басым болатын жоғары білім беру сапасын сыртқы бағалау. Бағалаудың бұл түріне көптеген еуропалық және посткеңестік елдерде қолданылатын мемлекеттік бақылау, лицензиялау, мемлекеттік аккредиттеу жатады.

Екінші түрі - жоғары білім сапасын ішкі бағалау. Мұнда университеттің өзін-өзі бағалау процесі басым болады. Жоғары оқу орны өзінің ішкі процестерін бағалайды және ұсынылатын білім беру қызметтерінің сапа деңгейін анықтайды. Бағалаудың бұл түрі жоғары білімді орталықтандырылған мемлекеттік басқару жоқ елдерде жиі кездеседі (АҚШ және оның тәжірибесін алған елдер) [2, 3].

Бүгінгі таңда Қазақстанда бірінші типтегі жоғары білім беру сапасын бағалау моделі қолданылады. Жоғары білім сапасын бағалаудың отандық жүйесі лицензиялау, мемлекеттік бақылау және аккредиттеу рәсімдерінен тұрады.

Бұл ретте, Қазақстан Республикасының «Білім туралы» Заңына сәйкес, білім беру жүйесіндегі мемлекеттік бақылау жоспардан тыс тексеру, бақылау субъектісіне (объектісіне) бару арқылы профилактикалық бақылау және бақылау субъектісіне (объектісіне) бармай профилактикалық бақылау деген нысандарда жүзеге асырылады [4, 59 бап]. 
Профилактикалық бақылауды тағайындау үшін уәкілетті мемлекеттік орган бақылау субъектісінің тікелей қызметіне байланысты сандық және сапалық көрсеткіштер жиынтығынан тұратын тәуекелдерді бағалау жүйесі деп аталатын іс-шаралар кешенін жүргізеді [5].

Қазақстан Республикасының «Рұқсаттар және хабарламалар туралы» Заңына сәйкес жоғары білім беру саласында білім беру қызметін іске асыру лицензиялауға жатады, ол заңды тұлғаның білім беру қызметіне қойылатын біліктілік талаптарында бекітілген ең төменгі сандық және сапалық нормативтер мен көрсеткіштерге сәйкестігін айқындауға бағытталған [6]. 2018 ж. жоғары оқу орындары автономиясының кеңеюімен жоғары білім беру саласындағы лицензиялау кадрларды даярлау бағыттары бойынша жүргізіледі. Бұл өзгеріс жоғары оқу орындарына кадрларды даярлаудың неғұрлым кең бағыты бойынша лицензия алуға мүмкіндік берді, оның шеңберінде олар түрлі білім беру бағдарламаларын ұсына алады.

Қазақстандық жоғары білім беру жүйесінің Болон процесіне қосылуымен 2010 ж. сапаны қамтамасыз ету құралдарының бірі ретінде тәуелсіз аккредиттеу, оның ішінде институционалдық (білім беру ұйымының сапасын бағалау процесі) және мамандандырылған (жекелеген білім беру бағдарламаларының сапасын бағалау) аккредиттеу қолданылады. Білім беру саласындағы уәкілетті орган танылған аккредиттеу органдары тізілімін реттеуші болып табылады [7].

Сонымен бірге, аккредиттеу органдарын тану жөніндегі нормативтік актілерге енгізілген соңғы өзгерістердің бірі - білім беру ұйымының ұсынымы негізінде жоғары білім берудегі сапаны қамтамасыз ету жөніндегі Еуропалық қауымдастықтың (ENQA), сапаны қамтамасыз ету жөніндегі Азия-Тынық мұхиты желісінің (APQN) және АҚШ-тағы жоғары білімді аккредиттеу жөніндегі кеңестің (CHEA) халықаралық сапа тобының толық құқықты мүшелігіне кіретін шетелдік аккредиттеу органын тану мүмкін болып табылады.

Осы өзгерістерді ескере отырып, АҚШ-тағы бизнес мектептер мен бағдарламаларды аккредиттеу жөніндегі кеңес (ACBSP), бизнес-білім беруді бағалау жөніндегі жетекші мамандандырылған орган қазақстандық тізілімге соңғы болып енді. Осылайша, мұндай жаңашылдық қазақстандық сапаны қамтамасыз ету жүйесіне үздік аккредиттеу органдарын, оның ішінде кадрларды даярлаудың белгілі бір бағыты бойынша мамандандырылған органдарды тартуға мүмкіндік береді.

Жалпы бүгінгі таңда тізілімге 11 аккредиттеу органы, оның ішінде 5 халықаралық және 6 қазақстандық аккредиттеу органы кіреді [8]. Аккредиттеудің болуы жоғары оқу орындарына мемлекет тарапынан қаржыландыру алуға және өзіндік үлгідегі дипломдар беруге мүмкіндік береді [4, 59 және 62 баптар].

Сонымен қатар, Қазақстанда қолданыстағы мемлекеттік бақылау және жоғары білім сапасын қамтамасыз ету жүйесі негізделген әдіснамалық тәсілдер мен нормативтік әзірлемелерге қарамастан, сандық деректерді растауға және нормативтік актілерге сәйкестікке тексеруге ғана бағытталған. Мұндай жағдайда сапа деңгейін айқындау, бар проблемаларды анықтау, сондайақ жоғары білім сапасын жақсарту үшін тиімді шешімдерді қалыптастыру қиын.

Осылайша, жоғары білім сапасын басқарудың ұлттық жүйесін жетілдіру процесін қолдану мақсатында жоғары білім сапасын бағалаудың жоғарыда аталған модельдерінің ерекшеліктері мен бәсекелестік артықшылықтарын анықтау үшін АҚШ, Ұлыбритания, Финляндия және Норвегия елдерінде сапаны қамтамасыз ету процестерін егжей-тегжейлі қарау орынды болып табылады.

Сапаны бағалаудың американдық моделі екінші типке жатады және университеттің өзін ішкі бағалауына негізделген. Ол үшін жоғары оқу орны ағымдағы мақсаттарды, міндеттер мен ресурстарды ескере отырып, өзінің стратегиясын, бағдарламасын және бағалау әдістемесін әзірлейді. Өзін-өзі бағалау кезінде жүргізілген кешенді талдау университетке білім беру процесін жетілдіру бойынша басқарушылық шешімдерді өз уақытында қабылдауға және жоғары білім сапасын басқару бойынша түзетулер енгізуге мүмкіндік береді.

Федералды деңгейде университеттерді бақылауды жүзеге асыратын бірыңғай мемлекеттік орган жоқ, бірақ АҚШ білім департаменті аккредиттеуді жүзеге асыратын органдардың тізімін жасайды. Сондай-ақ, жоғары білім беруді аккредиттеу жөніндегі кеңес (Council for Higher Education Accreditation-CHEA) жұмыс істейді, ол аккредиттеу органдарының қызметін академиялық сапаны ілгерілетудегі олардың тиімділігі тұрғысынан бақылайды [9]. 
Сондай-ақ, Арнайы және кәсіби аккредиттеу ұйымдарының Қауымдастығы (Association of specialized and Professional Accreditors-ASPA) бар, оның негізгі мақсаты - білім беру және аккредиттеу сапасын арттыру. ASPA мүшелері аккредиттеу процесін жүргізу кезінде басшылыққа алатын ASPA (Code of Good Practice) Тиісті тәжірибе кодексін сақтайды[10].

АҚШ-тағы мемлекеттік бақылау аккредиттеу ретінде «төменнен», яғни университеттің бастамасы бойынша ерікті түрде жүзеге асырылады. Қазіргі кезеңде АҚШ-та аккредиттеуді Университеттер қауымдастығы, 4 және 2 жылдық колледждер қауымдастығы, Америкалық медициналық қауымдастық, Кәсіби даму мәселелері жөніндегі инженерлер кеңесі және т.б. сияқты үкіметтік емес ұйымдар жүргізеді.

АҚШ-тың әрбір аккредиттеу агенттігі жоғары білім сапасын бағалау критерийлерін анықтап, егжей-тегжейлі сипаттайды, олар кеңінен талқыланып, университеттерге жеткізіледі. Бұл критерийлерді келесі негізгі бағыттарға бөлуге болады:

1. Университетті жоспарлаудың тұтастығы мен басқарудың тиімділігі;

2. Білім беру бағдарламалары және оларды сапалы профессорлық-оқытушылық құраммен қамтамасыз ету;

3. Білім алушыларға сапалы білім алу үшін жағдай жасауды қамтамасыз ету (оларға қызмет көрсету, материалдық ресурстар, ақпараттық техникалық қамтамасыз ету) [11].

Жалпы, жоғары білім сапасын бағалаудың американдық моделі өзін-өзі реттеуге және «академиялық еркіндік» тұжырымдамасына негізделген, яғни университеттер, әсіресе Үкімет тарапынан сыртқы бақылаусыз өз бизнестерін жүргізу еркіндігіне ие [12].

XX ғасырдың басында жоғары білім сапасын қамтамасыз ету процестерін бастаған алғашқы Еуропа елдерінің бірі - Ұлыбритания. Білім беру сапасын басқарудың заманауи Британдық моделінің басты ерекшелігі - мониторинг және сапаны бақылау рәсімдеріне қатысатын мамандандырылған делдалдық агенттіктердің алуан түрлілігі. Атап айтқанда, жетекші рөл білім беру курстарының сапасын бағалайтын үкіметтік ұйым - Сапаны қамтамасыз ету агенттігіне (Quality Assurance Agency - QAA) жатады, Жоғары мектеп статистикасы агенттігі - білім беру деректерін жинақтауға жауап береді, Жоғары мектептің талдау институты - үкіметтің тапсырысы бойынша білім беру саласында зерттеулер жүргізеді.

Аккредиттеуден өту кезінде университеттерге мынадай талаптар қойылады:

- тиісті білім беру ортасын құру және білім беру бағдарламаларын іске асырудағы дербестік;

- тиімді академиялық белсенділікті ұйымдастыру;

- сапа кепілдігінің тиімді жүйесінің жұмыс істеуі;

- сыртқы ұсынымдар үшін ашықтық;

- қаржылық тұрақтылық [11].

Жалпы, Ұлыбритания университеттері корпоративтік басқаруды ескере отырып, сапаны қатаң ішкі өзін-өзі бақылауды қамтамасыз етеді, бірақ жоғары оқу орындарының ғылыми-білім беру қызметінің сапасын бақылау мемлекеттік органдардың қатысуымен жүзеге асырылады.

Сапаны қамтамасыз етудегі үздік тәжірибені қарастыру кезінде Скандинавия елдерінің тәжірибесін, атап айтқанда, өзінің білім беру жүйелерінің арқасында соңғы жылдары БҰҰ рейтингінің алғашқы бестігінде тұрған Финляндия мен Норвегияның жоғары білім беру сапасын қамтамасыз ету жүйесін зерделеу маңызды.

Жоғары білім сапасын қамтамасыз етудің фин моделі университеттердің сыртқы сапасын бағалауды және өзін-өзі бағалауды қамтиды. Сондай-ақ сыртқы бақылаушылар тарапынан жекелеген құрылымдарды тексеру қолданылады.

1995 ж. бастап сапаны бақылаудың ұлттық органы - Білім беруді бағалау жөніндегі фин кеңесі (Finnish Education Evaluation Centre (FINEEC) құрылған, ол қызметінің сипаты бойынша бақылаушы емес, консультативтік орган. Кеңестің негізгі міндеті - тәуелсіз сарапшы орган ретінде университеттердің сапасын қамтамасыз ету жүйелеріне, оның ішінде жоғары оқу орнының оқыту сапасын және зерттеулерді жүргізуді қолдауға және жетілдіруге мүмкіндік беретін процестері мен әдістеріне сыртқы бағалау немесе аудит жүргізу. Сондай-ақ, Кеңес жоғары оқу орындары мен білім беру министрлігіне білім беру ұйымдарының ішіндегі бағалау жүйесі үшін мамандар даярлау, кәсіптік бағдарланған институттарды, қолданбалы ғылымдар университеттерін аккредиттеу үшін материалдарды әзірлеу мен дайындау арқылы бағалау жүйесін жетілдіруде жәрдем көрсетеді [13]. 
Жоғары оқу орны қызметін бағалау мынадай негізгі көрсеткіштерге негізделеді:

1. Жоғары оқу орны қызметі бағытының міндеттері мен бейіні;

2. Оқыту бағдарламалары мен курстарын әзірлеу сапасы;

3. Оқытушылар құрамының педагогикалық қызметі және оның нәтижелері;

4. Халықаралық және салааралық ынтымақтастық, институционалдық желілік байланыстар [14].

Сапаны қамтамасыз етуді сырттай бағалаумен қатар білім беру саласындағы фин заңнамасы білім берудің барлық деңгейлерінде өзін-өзі бағалауды жүргізуді талап етеді. Осыған байланысты өзін-өзі бағалауды жоғары оқу орындарының ұжымы өз жұмысының маңызды құрамдас бөлігі ретінде қабылдайды және өзін-өзі бағалау нәтижелері бойынша салыстырмалы талдау жалпы сапаның жақсаруын ынталандырады.

Сондай-ақ, Финляндияда бірыңғай міндетті құжатты ала отырып, лицензиялаудан өту рәсімі қолданылатынын атап өту қажет. Университетті құру үшін маңызды критерий жоғары оқу орны құрылатын жердің демографиялық жағдайын ескере отырып, орындылықты негіздеу болып табылады.

Білім беру қызметін жүргізуге рұқсат берудің мұндай тәжірибесі Норвегияда да қолданылады, бірақ кәсіби қоғамдастықтармен бірлесіп қосымша қаралады [15]. Сондай-ақ, докторантураны қоса алғанда, жаңа бағдарламаларды әзірлеуге рұқсаты жоқ университеттер алдымен оларды аккредиттеуі керек. Сонымен қатар, жоғары оқу орындары аккредиттеу процесі арқылы университет мәртебесін алуға өтініш бере алады.

Норвегияда сапаны бағалау процесін жоғары оқу орнының өзін-өзі бағалауы жүргізілгеннен кейін үкімет қаржыландыратын ұйымдар жүзеге асырады. Норвегиялық сапаны қамтамасыз ету жүйесі бақылау және дамыту функциясын орындайды, өйткені ол сапаны қамтамасыз ету жүйелерін жетілдіруге ұсыныстар береді. Институционалдық аккредиттеу критерийлері сапаны ішкі қамтамасыз ету, академиялық құзыреттілік деңгейі, зерттеу қызметі, қолданыстағы бағдарламалардың саны мен деңгейі, интернационалдандыру, инфрақұрылым және институционалдық ұйымдастыру мен басқару бойынша анықталады.

2003 ж. Болон процесіне сәйкес норвегиялық жоғары білім беру жүйесінде жоғары білім сапасын сақтауға және арттыруға бағытталған кешенді сапа реформасы жүргізілді. Осы реформаның нәтижесінде университеттер мен колледждердің сапасын сыртқы қамтамасыз етуге жауапты тәуелсіз орган - Білім беру сапасын қамтамасыз ету жөніндегі норвегиялық агенттік (Nasjonal organ for kvalitet i utdannigen (NOKUT) құрылды. NOKUT 6 жылдық цикл мерзімінде жоғары оқу орындарының ішкі сапа кепілдігі аудитін жүргізу арқылы білім беру сапасын бақылау және дамыту стратегиясын қолданады.

Университеттерге бару және жоғары оқу орындарының жылдық есептерін қарау негізінде сараптамалық топ аудитті жүргізеді. Егер аудит нәтижелері қанағаттанарлықсыз болса, келесі 6 ай ішінде жаңа аудит жүргізілетін болады. Бірақ егер соңғы аудит нәтижесінде бағалау да қанағаттанарлықсыз болса, онда университет білім беру қызметін жүргізу құқығынан айырылады.

Жалпы алғанда, жоғары білім сапасына қойылатын жаңа талаптар және Норвегияның жоғары білім сапасын бағалау жөніндегі бірыңғай органын құру ашықтық және сапа мәселелері туралы хабардарлықты арттыру тұрғысынан сапаға оң әсер етті [16].

\section{Талқылаулар}

Шет елдердің жоғары білім беру сапасын бағалау модельдерін және сапасын қамтамасыз ету жүйелерін қалыптастыру тәсілдерін талдау негізінде қазақстандық сапаны қамтамасыз ету жүйесін жетілдіру үшін мынадай оң аспектілерді бөліп көрсетуге болады:

Ұлыбритания және АҚШ университеттерінің сапаны сыртқы бақылаудан тәуелсіздігі және жоғары оқу орындарының ішкі өзін-өзі бағалауын дамыту. Осыны ескере отырып, сапаны қамтамасыз етудің қазақстандық жүйесі жоғары оқу орындарының сапасын қамтамасыз етудің ішкі жүйелерін бағалаудың жаңа тетіктері мен құралдарын әзірлеуі қажет; 
Жоғары оқу орындарын аккредиттеу жүйесінің американдық моделі қазіргі кезеңде «төменнен аккредиттеу» ерекшелігі бар жоғары білім сапасын басқару тетіктерінің негізі болып табылады;

Сапаны қамтамасыз етудің финдік және норвегиялық моделінде демографиялық жағдайды ескере отырып, университетті құрудың орындылығын негіздеу қажеттілігі. Қазақстандық жоғары білім беру жүйесінде осы тәсілді қолдану кадрларға қажеттілікті және демографиялық жағдайды ескере отырып, лицензиялау процесін реттеуге мүмкіндік берер еді;

Финляндия мен Норвегияда білім беру сапасын бағалау жөніндегі тәуелсіз бірыңғай ұлттық органның құрылуы жоғары білім беру сапасын арттырудың оң нәтижелерін көрсетті. Қазақстандық жоғары білім беру жүйесіне осындай тәсіл енгізілген жағдайда, жоғары білім беру сапасын бағалаудың барлық қолда бар сыртқы және ішкі құралдарын бірыңғай институционалдық органға шоғырландыруға мүмкіндік берер еді.

\section{Қорытынды}

Осылайша, шетелде де, Қазақстанда да жоғары білім беру сапасын бағалау жүйесі білім беру қызметтерін тұтынушылардың мүдделерін қорғауға және ел экономикасын жоғары білікті кадрлармен қамтамасыз етуге бағытталған.

\section{ӘДЕБИЕТТЕР}

1 Қазақстан Республикасы Президентінің Жарлығы. Қазақстан Республикасының 2025 жылға дейінгі Ұлттық даму жоспарын бекіту және Қазақстан Республикасы Президентінің кейбір жарлықтарының күші жойылды деп тану туралы: 2018 жылғы 15 ақпандағы № 636 бекітілді. URL: https://adilet. zan.kz/kaz/docs/U1800000636

2 Шестакова M.В. Зарубежные модели оценки качества высшего образования // Экология человека. - 2008. - № 11. URL: https://cyberleninka.ru/article/n/zarubezhnye-modeli-otsenki-kachestva-vysshegoobrazovaniya

3 Гривенная Е.Н. Сравнительный анализ международного и российского опыта управления качеством высшего профессионального образования // Вестник ВИ МВД России. - 2011. - № 1. URL: https://cyberleninka.ru/article/n/sravnitelnyy-analiz-mezhdunarodnogo-i-rossiyskogo-opyta-upravleniyakachestvom-vysshego-professionalnogo-obrazovaniya.

4 Қазақстан Республикасының Заңы. Білім туралы: 2007 жылғы 27 шілдедегі № 319-III. URL: http:// https://adilet.zan.kz/kaz/docs/Z070000319

5 Қазақстан Республикасы Білім және ғылым министрінің м.а. 2015 жылғы 31 желтоқсандағы № 719 және Қазақстан Республикасы Ұлттық экономика министрінің м.а. 2015 жылғы 31 желтоқсандағы № 843 бірлескен бұйрығы. Білім беру жүйесіне тексеру жүргізу бойынша тәуекел дәрежесін бағалау өлшемшарттары мен тексеру парақтарын бекіту туралы. URL: https:/adilet.zan.kz/kaz/docs/V1500012777

6 Қазақстан Республикасының Заңы. Рұқсаттар және хабарламалар туралы: 2014 жылғы 16 мамырдағы № 202-V. URL: https://adilet.zan.kz/kaz/docs/Z1400000202

7 Қазақстан Республикасы Білім және ғылым министрінің бұйрығы. Аккредиттеу органдарын, оның ішінде шетелдік аккредиттеу органдарын тану және танылған аккредиттеу органдарының, аккредиттелген білім беру ұйымдарының және білім беру бағдарламаларының тізілімдерін қалыптастыру қағидаларын бекіту туралы: 2016 жылғы 1 қарашадағы № 629. URL: https://adilet.zan.kz/kaz/docs/ V1600014438

8 Реестр признанных аккредитационных органов. URL: https://enic-kazakhstan.kz/ru/accreditation/ accredited_organizations

9 https://www.chea.org/about-chea

10 https://aspa-usa.org/code-of-good-practice/

11. Найзабеков А.Б. Оценка качества высшего образования / А.Б. Найзабеков, О.В. Чалая // Вест. Караганд. У-та. Педагогика. - 2012. - № 2(66). - С. 15-19.

12. Werner D. Higher Education Accreditation: An Overview // Final Draft, LORC Presentation, Kyoto, Japan. November. - 2004. - T. 23. 
13 https://karvi.fi/en/fineec/

14 Пчелинцев В.С. Государственная политика в области высшего образования в Финляндии: приоритеты и механизмы регулирования / В.С. Пчелинцев // Актуальные проблемы Европы. - 2013. № 2. - C. 83-113.

15 Каракчиева И.В., Южакова Т.А. Лицензирование и аккредитация особенности государственного регулирования в странах организации экономического сотрудничества и развития // Проблемы науки. 2015. - № 3(33).

16 Kalpazidou Schmidt E. Quality assurance policies and practices in Scandinavian higher education systems: convergence or different paths? // Journal of Higher Education Policy and Management. 2017. V. 39. No. 3. P. $247-265$.

\section{REFERENCES}

1 Қаzaқstan Respublikasy Prezidentiniң Zharlyғy. Қазақstan Respublikasynyң 2025 zhylғa dejingi ¥lttyқ damu zhosparyn bekitu zhəne Қаzақstan Respublikasy Prezidentiniң kejbir zharlyқtarynyң kүshi zhojyldy dep tanu turaly: 2018 zhylғy 15 ақрапдағу № 636 bekitildi. URL: https://adilet.zan.kz/kaz/docs/U1800000636

2 Shestakova M.V. Zarubezhnye modeli ocenki kachestva vysshego obrazovanija // Jekologija cheloveka. - 2008. - № 11. URL: https://cyberleninka.ru/article/n/zarubezhnye-modeli-otsenki-kachestva-vysshegoobrazovaniya

3 Grivennaja E.N.(2011) Sravnitel'nyj analiz mezhdunarodnogo i rossijskogo opyta upravlenija kachestvom vysshego professional'nogo obrazovanija // Vestnik VI MVD Rossii. No. 1. URL: https:/cyberleninka.ru/ article/n/sravnitelnyy-analiz-mezhdunarodnogo-i-rossiyskogo-opyta-upravleniya-kachestvom-vysshegoprofessionalnogo-obrazovaniya.

4 Қазақstan Respublikasynyн Zаңу. Bilim turaly: 2007 zhylғy 27 shildedegi № 319-III. URL: http:// https://adilet.zan.kz/kaz/docs/Z070000319

5 Қаzaқstan Respublikasy Bilim zhəne ғуlym ministriniң m.a. 2015 zhylғy 31 zheltoқsandaғy No. 719 zhəne Қазақstan Respublikasy Ұlttyқ jekonomika ministriniң m.a. 2015 zhylғy 31 zheltoқsandaғy No. 843 birlesken bұjryғy. Bilim beru zhyjesine tekseru zhyrgizu bojynsha təuekel dərezhesin baғalau elshemsharttary men tekseru paraktaryn bekitu turaly. URL: https://adilet.zan.kz/kaz/docs/V1500012777

6 Қаzақstan Respublikasynyң Zаңу. Rұқsattar zhəne habarlamalar turaly: 2014 zhylғy 16 mamyrdaғy № 202-V. URL: https://adilet.zan.kz/kaz/docs/Z1400000202

7 Қаzaқstan Respublikasy Bilim zhəne ғуlym ministriniң bұjryғу. Akkreditteu organdaryn, оnуң ishinde sheteldik akkreditteu organdaryn tanu zhəne tanylғan akkreditteu organdarynyң, akkredittelgen bilim beru ұјymdarynyң zhəne bilim beru baғdarlamalarynyң tizilimderin қаlyptastyru қafidalaryn bekitu turaly: 2016 zhylғy 1 қаrashadaғy No. 629. URL: https://adilet.zan.kz/kaz/docs/V1600014438

8 Reestr priznannyh akkreditacionnyh organov. URL: https://enic-kazakhstan.kz/ru/accreditation/ accredited_organizations

9 https://www.chea.org/about-chea

10 https://aspa-usa.org/code-of-good-practice/

11. Najzabekov A.B. (2012) Ocenka kachestva vysshego obrazovanija / A.B. Najzabekov, O.V. Chalaja // Vest. Karagand. u-ta. Pedagogika. No. 2(66). - pp. 15-19.

12. Werner D. (2004.) Higher Education Accreditation: An Overview // Final Draft, LORC Presentation, Kyoto, Japan. November. V. T. 23.

$13 \mathrm{https}: / /$ karvi.fi/en/fineec/

14 Pchelincev V.S. (2013) Gosudarstvennaja politika v oblasti vysshego obrazovanija v Finljandii: prioritety i mehanizmy regulirovanija / V.S. Pchelincev // Aktual'nye problemy Evropy. No. 2, pp. 83-113.

15 Karakchieva I.V., Juzhakova T.A. (2015) Licenzirovanie i akkreditacija osobennosti gosudarstvennogo regulirovanija v stranah organizacii jekonomicheskogo sotrudnichestva i razvitija // Problemy nauki. No. 3(33).

16 Kalpazidou Schmidt E. (2017) Quality assurance policies and practices in Scandinavian higher education systems: convergence or different paths? // Journal of Higher Education Policy and Management. V. 39. No. 3. P. 247-265. 
Ш.К. СУЛЕЙМЕНОВА, *1

докторант.

*e-mail: sh.suleimenova@apa.kz

${ }^{1}$ Академия государственного управления при Президенте Республики Казахстан, Казахстан, г. Нур-Султан

\title{
СИСТЕМЫ УПРАВЛЕНИЯ КАЧЕСТВОМ ВЫСШЕГО ОБРАЗОВАНИЯ (НА ПРИМЕРЕ США, ВЕЛИКОБРИТАНИИ, НОРВЕГИИ И ФИНЛЯНДИИ)
}

\begin{abstract}
Аннотация
Казахстан на современном этапе находится в новых социально-политических, экономических и международных условиях, вызванных растущей глобализацией. Это обусловливает, с одной стороны, значительное влияние на развитие системы образования Казахстана мировых образовательных тенденций, с другой стороны, рыночный характер национальной экономики определяет неизбежность влияния образования, в целом, и образовательных услуг, в частности, на экономику страны и ее развитие посредством капитализации знаний. В настоящее время казахстанские вузы развиваются в соответствии с тенденциями, сложившимися в мировой и отечественной экономике, среди которых особо выделяется глобализация. Для современного казахстанского высшего образования характерно стремление интегрироваться в мировое образовательное пространство. Целью данной статьи является исследование международного опыта по управлению качеством высшего образования на примере некоторых европейских стран и США. Охарактеризованы современные две модели управления качеством высшего образования в мировом образовательном пространстве и определена модель оценки качества высшего образования в Казахстане. Проанализировано казахстанское законодательство в сфере государственного контроля и оценки качества высшего образования. Определены лучшие подходы оценки качества высшего образования для казахстанской системы высшего образования по примеру рассматриваемых зарубежных стран. Для написания статьи использованы такие методы исследования, как анализ правовых актов и документов, кейс-стади, дедукция и обобщение.
\end{abstract}

Ключевые слова: государственное управление, высшее образование, управление качеством, оценка, аккредитация, мировое образовательное пространство, анализ.

\author{
SH.K. SULEIMENOVA, $* 1$ \\ PhD student. \\ *e-mail: sh.suleimenova@apa.kz \\ ${ }^{1}$ Academy of Public Administration under \\ the President of the Republic of Kazakhstan, \\ Kazakhstan, Nur-Sultan
}

\section{QUALITY MANAGEMENT SYSTEMS OF HIGHER EDUCATION (BASED ON THE EXAMPLE OF THE USA, GREAT BRITAIN, NORWAY AND FINLAND)}

\begin{abstract}
At the present stage, Kazakhstan is in new socio-political, economic and international conditions caused by growing globalization. This determines, on the one hand, a significant impact on the development of the education system of Kazakhstan of world educational trends, on the other hand, the market nature of the national economy determines the inevitability of the impact of education in general, and educational services, in particular, on the country's economy and its development through the capitalization of knowledge. Currently, Kazakhstan's universities are developing in accordance with the trends that have developed in the world and domestic economy, among which globalization stands out. The modern Kazakh higher education is characterized by the desire to integrate into the world educational space. The purpose of this article is to study the international experience in managing the quality of higher education on the example of some European countries and the United States of America. The modern two models of quality management of higher education in the global educational space are characterized and the model of assessing the quality of higher education in Kazakhstan is determined. The article analyzes the Kazakh legislation in the field of state control and assessment of the quality of higher education. The best approaches to assessing the quality of higher education for the Kazakh higher education system have been identified, following the example of the foreign countries under consideration. To write the article such methods of research as analysis of legal acts and documents, case study, deduction and generalization were used.
\end{abstract}

Key words: public administration, higher education, quality management, assessment, accreditation, world educational space, analysis. 